\title{
PENGEMBANGAN LIFE SKILL UNTUK KEMANDIRIAN ANAK DI PANTI ASUHAN BUDI UTOMO MUHAMMADIYAH METRO
}

\author{
E-ISSN: 2721-7531 \\ http://jurnal-stidnatsir.ac.id/index.php/index \\ DOI: 10.38214/jurnalbinaummatstidnatsir.v3i02.74
}

Submitted: 30-10-2020 Reviewed: 29-11-2020 Published: 20-12-2020

Ari Saputra

arishaputra03@gmail.com

STID Mohammad Natsir, Indonesia
Salman Alfarisi

Alfarisi784@gmail.com

STID Mohammad Natsir, Indonesia

\begin{abstract}
ABSTRAK
Tujuan penelitian: Tujuan penelitian ini adalah untuk mengungkap bagaimana pengembangan life skill untuk kemandirian anak di Panti Asuhan Budi Utomo Muhammadiyah Metro. Metode penelitian, jenis penelitian ini adalah penelitian lapangan (field researcb), yaitu penelitian dan pengambilan datanya dilakukan di lapangan, dengan menggunakan pendekatan kualitatif dengan metode deskriptif kualitatif . Hasil penelitian, Berdasarkan hasil penelitian, Panti Asuhan Budi Utomo Muhammadiyah Metro telah berusaha melakukan kegiatan-kegiatan yang dapat mengembangkan Life Skill untuk kemandirian Anak-anak asuhnya. Pengembangan life skill untuk kemandirian anak-anak asuh tersebut paling tidak dilakukan dengan cara pengembangan Life Skill untuk Kemandirian Anak Melalui pendidikan baik agama maupun umum, melalui keterampilan komunikasi, melalui tata boga, melaui pertanian, melalui Kesenian, dan melalui peternakan.

Kata Kunci: Pengembangan, Lifeskill, Kemandirian, Panti Asuhan
\end{abstract}

\section{PENDAHULUAN}

Pada saat ini perkembangan zaman terjadi begitu sangat cepat, mulai dari perkembangan sosial budaya, politik, ekonomi, teknologi, serta pertumbuhan penduduk yang cukup cepat, secara tidak langsung telah mempengaruhi tatanan nilai dan budaya suatu bangsa. Terlebih lagi memasuki zaman sekarang ini, anak remaja banyak dihadapkan dengan berbagai problema kehidupan, baik itu persoalan yang mencakup 
lingkungan keluarga, lingkungan sekolah, lingkungan masyarakat, dan lingkungan dunia kerja yang penuh dengan persaingan ketat.

Masalah remaja ini sudah menjadi kenyataan sosial dalam masyarakat. Terlebih lagi kalau dipertimbangkan bahwa remaja sebagai generasi penerus adalah yang akan mengisi berbagai posisi dalam masyarakat dimasa yang akan datang, yang akan meneruskan kehidupan masyarakat bangsa dan negara dimasa depan. Maka pembahasan mengenai masalah remaja secara tuntas dan mendalam tidak dapat dihindari lagi. ${ }^{1}$

Pada waktu anak memasuki masa remaja terjadi perubahan yang hebat oleh pertumbuhan dan kematangan fisiknya. Perubahan fisik ini diikuti pula dengan perubahan psikologis. Masa remaja yang berlangsung lama sebenarnya diberikan oleh masyarakatnya agar mampu mengintegrasikan dirinya dalam kehidupan dewasa. Pada remaja timbul pertanyaan-pertanyaan siapa saya? Dan akan menjadi apa nanti? Merupakan pertanyaan yang bersangkut paut dengan perkembangan psikososial dan yang tidak mudah untuk dijawab. ${ }^{2}$

Dalam menghadapi permasalahan-permasalahan oleh anak-anak remaja di masa kini, sangat dibutuhkan life skill guna memenuhi kebutuhan yang diperlukan. Tentunya setiap anak memiliki bakat dan kecakapan dalam dirinya masing-masing. Selain itu, anak remaja juga memiliki rasa ingin tahu yang tinggi sehingga remaja cenderung ingin berpetualang dan ingin mengetahui segala sesuatu dan mencoba segala sesuatu yang belum pernah dicobanya. Oleh karena itu amat penting bagi remaja diberikan bimbingan agar rasa ingin tahunya yang tinggi itu dapat terarah kepada kegiatan-kegiatan yang positif, kreatif dan produktif.

Jika keinginan semacam itu mendapatkan bimbingan dan penyaluran yang baik akan menghasilkan kreatifitas remaja yang sangat baik, seperti kemampuan membuat alat elektronik untuk kepentingan komunikasi, menghasilkan temuan ilmiah yang bermutu dan berguna. Situasi kehidupan dewasa ini sudah semakin kompleks. Kompleksitas kehidupan seolah-olah telah menjadi bagian yang mapan dari kehidupan masyarakat, sebagian akan bergeser atau bahkan mungkin hilang sama sekali karena

${ }^{1}$ Sarlito W Sarwono, Psikologi Remaja Edisi Revisi, Jakarta: Raja Grafindo Persada, 2010, hal. 5

${ }^{2}$ Singgih D. gunarsa “Dasar Dan Teori Perkembangan Anak”, Jakarta: Libri, 2011, hal. 112. 
digantikan oleh pola kehidupan baru pada masa mendatang yang diperkirakan semakin kompleks. ${ }^{3}$

Permasalahan masih tingginya angka pengangguran, juga diakui oleh kepala Badan Pusat Statistik (BPS) Suhariyanto. "Jumlah pengangguran terbuka pada Agustus 2019 sebesar 7,05 juta orang. Angka tersebut naik secara jumlah dibandingkan Agustus 2018 sebesar 7 juta orang", ujar Suhariyanto dalam konferensi pers di Jakarta, Selasa (5/11/2019). Saat ini tingkat pengangguran terbuka pada Agustus 2019 untuk lulusan SMK mencapai 10,42\%, kemudian disusul oleh lulusan SMA sebesar 7,92\%. Nilai atau IPK tinggi bukan menjadi faktor utama di dunia kerja. Akan tetapi keahlian dan skill menjadi bukti apakah pantas menyandang nilai atau IPK yang tinggi tersebut atau tidak. Selain lapangan perkerjaan yang terbatas, faktor penyebab pengangguran adalah kurangnya pengetahuan yang diakibatkan karena banyaknya anak remaja yang putus sekolah. ${ }^{4}$

Selain lapangan perkerjaan yang terbatas, kurangnya pengetahuan, salah satu faktor penyebab pengangguran. Selain itu, juga dipengaruhi kurangnya keterampilan hidup (life skill). Faktor lainnya adalah karena kemiskinan dan keluarga (orang tua) yang sudah tiada. Salah satu cara yang dapat dilakukan untuk mendukung terlantar, anak yatim piatu (tidak memiliki orang tua) baik karena faktor keluarga, ekonomi, atau kemiskinan adalah dengan cara menyakurkan mereka kepada panti asuhan. Adanya kekurangan yang dialami oleh anak-anak tersebut memberikan dampak kepada mereka yaitu lemahnya diri untuk mengembangkan kemampuan yang dimilikinya.

Salah satu lembaga yang berupaya melakukan pengembangan kecakapan hidup atau life skill untuk kemandirian anak adalah Panti Asuhan Budi Utomo Muhammadiyah Metro. Panti Asuhan Budi Utomo Muhammadiyah Metro adalah panti asuhan tertua di Propinsi Lampung, yang didirikan tokoh-tokoh MASYUMI sejak 20 Mei tahun 1946. Karena padatnya kegiatan partai pada waktu itu, maka mereka menjalin kerja sama dengan Muhammadiyah yang secara resmi pengelolaanya diserahkan kepada Muhammadiyah pada tahun $1952 .^{5}$

\footnotetext{
${ }^{3}$ Ibid, hal. 107

${ }^{4}$ Eksis Sindonews, website: https://eksis.sindonews.com/ 29 Desember 2019

5 Ari Febrian, Panti Asuhan Budi Utomo Muhammadiyah Metro, Wawancara, Metro, 17 Desember 2019
} 
Latar belakang didirikannya Panti Asuhan ini adalah didorong oleh beberapa situasi pada saat itu, antara lain banyaknya janda dan wanita jompo yang ditinggal mati/hilang oleh suami mereka ketika menjalani ROMUSHA (pada masa penjajahan Jepang maupun ketika memperjuangkan dan mempertahankan kemerdekaan Republik Indonesia, banyaknya anak-anak penyandang status sosial seperti; yatim, piatu, yatim piatu, maupun terlantar karena situasi di atas dan memenuhi panggilan Allâh SWT sebagaimana tercantum di dalam QS Al-Ma un ayat 1-3, Menjalankan amanat UUD 45 pasal $34 .^{6}$

Berdasarkan observasi yang peneliti lakukan, peneliti melihat bahwa Panti Asuhan Budi Utomo telah berupaya untuk melakukan pengembang life skill pada anak-anak binaanya. Diantra pengembangan life skill yang dilakukan oleh Panti Asuhan Budi Utomo untuk kemandirian anak adalah dengan melakukan pembinaan yang intensif kepada anak asuhnya, yang dilakukan hamper setiap hari. Bentuk pembinaan tersebut adalah mengembangkan life skill (kecakapan hidup) melalui pendidikan keagamaan, yaitu dengan belajar membaca, menulis, membaca al-Qur'an, hafalan al-Qur'an, hafalan hadits dan pelajaran lainnya. Kemudian pengembangan life skill (kecakapan hidup) melalui peternakan yaitu dengan beternak lele dan beternak ayam.

Selanjutnya pengembangan life skill (kecakapan hidup) melalui tata boga yaitu dengan latihan memasak, keterampilan interpersonal (komunikasi sosial) yaitu dengan kegiatan mubâdharab (latihan pidato atau ceramah) dan bahasa arab, melalui perkebunan yaitu dengan menanam tanaman, seperti bunga-bunga, cabai, singkong, aglonema dan tanaman lainnya, melalui kesenian yaitu kerajinan tangan dengan memanfaatkan barang-barang bekas dan melalui bela diri yaitu dengan bela diri tapak suci.

Tujuan dari pengembangan kecakapan hidup (life skill) di panti asuhan Budi Utomo yaitu pembinaan agamanya, menjadikan mereka lebih terampil serta memiliki kemandirian agar tidak bergantung kepada orang lain dalam kehidupannya di masyarakat nantinya.

Berdasarkan latar belakang dan permasalahan di atas, peneliti tertarik melakukan penelitian dengan judul "Pengembangan Life Skill untuk

\footnotetext{
${ }^{6}$ Sumber: Dokumentasi Panti Asuhan Budi utomo Muhammadiyah Metro, 20 Desember 2019
} 
Kemandirian Anak di Panti Asuhan Budi Utomo Muhammadiyah Metro".

\section{Pengembangan}

Pengembangan berasal dari kata kembang yaitu, yang mempunyai proses, cara, perbuatan mengembangkan. ${ }^{7}$ Secara etimologis, pengembangan berarti membina dan meningkatkan kualitas. Dalam pengertian lain, pengembangan sumber daya manusia diartikan sebagai memperluas horison pilihan bagi masyarakat banyak. ${ }^{8}$ Menurut Hadari pengembangan adalah usaha yang dilakukan secara formal dan berkelanjutan dengan difokuskan pada peningkatan dan penambahan kemampuan seorang pekerja. ${ }^{9}$

\section{Life Skill}

Life skill atau kecakapan hidup yaitu kecakapan untuk melakukan adaptasi dan perilaku positif yang memungkinkan seseorang untuk melakukan tindakan secara efektif dalam menghadapi kebutuhan dan tantangan sehari-hari. Kecakapan hidup pada intinya lebih menekankan pada penguasaan kecakapan yang memungkinkan seseorang untuk memperoleh mental yang memadai dan kompetensi bagi anak (remaja) dalam menghadapi kenyataan kehidupan sehari-hari. ${ }^{10}$ Kecakapan hidup adalah keterampilan anak untuk memahami dirinya dan potensinya dalam kehidupan, antara lain mencakup penentuan tujuan, memecahkan masalah, dan hidup bersama orang lain. ${ }^{11}$ Pengertian life skill menurut Malik Fajar adalah kecakapan yang dibutuhkan untuk bekerja selain kecakapan dalam bidang akademik. Sedangkan menurut Slamet life skill adalah kemampuan, kesanggupan dan keterampilan yang diperlukan oleh

${ }^{7}$ Pusat Pembinaan dan Pengembangan Bahasa, Kamus Besar Bahasa Indonesia Edisi Kedua, Jakarta: Balai Pustaka, 1999, hal. 473

${ }^{8}$ Nanih Machendrawaty dan Agus Ahmad Safei, Pengembangan Masyarakat Islam dari Ideologi, Strategi sampai Tradisi, Bandung: PT. Remaja Rosdakarya, 2001, Cet. I, hal. 29

${ }^{9}$ Nel Arianty, Manajemen Sumber Daya Manusia, Medan: Perdana Publishing, 2016, hal. 129

10 Ayu Nur Shaumi, "Pendidikan Kecakapan Hidup (Life Skill) dalam Pembelajaran SAINS di SD/MI”, Jurnal Pendidikan dan Pembelajaran Dasar, II, 2, Desember, 2015, hal. 242.

${ }^{11}$ Ibid., hal. 243 
seseorang untuk menjalankan kehidupan dengan nikmat dan bahagia. ${ }^{12}$ Menurut Anwar, program pengembangan (pendidikan) life skill adalah pengembangan (pendidikan) yang dapat memberikan bekal keterampilan yang praktis, terpakai, terkait dengan kebutuhan pasar kerja, peluang usaha dan potensi ekonomi atau industri yang ada di masyarakat. ${ }^{13}$

Sedangkan menurut Dr. Anwar, pengembangan life skill (kecakapan hidup) terbagi menjadi beberapa macam yaitu:

a. Kecakapan Personal (Personal Skill).

Kecakapan personal (personal skill) yaitu kecakapan yang diperlukan bagi seseorang untuk mengenal dirinya secara utuh. Kecakapan ini mencakup sebagai berikut: Kecakapan Kesadaran Diri yaitu penghayatan sebagai makhluk Tuhan Yang Maha Esa, anggota masyarakat dan Warga Negara, serta menyadari dan mensyukuri kelebihan dan kekurangan yang dimilikinya, sekaligus menjadikannya sebagai modal dalam meningkatkan dirinya sebagai individu yang bermanfaat bagi diri sendiri dan lingkungan. Kecakapan Berfikir Rasional (Thinking Skill) yaitu kecakapan yang diperlukan dalam pengembangan potensi berfikir. Kecakapan ini mencakup kecakapan menggali dan menemukan informasi, kecakapan mengolah informasi dan mengambil keputusan serta kecakapan memecahkan masalah secara kreatif. ${ }^{14}$

b. Kecakapan Sosial (Social Skill).

Kecakapan berkomunikasi yang dilakukan secara lisan maupun tulisan. Kemampuan mendengarkan dan menyampaikan gagasan secara lisan maupun tulisan perlu dikembangkan. Kecakapan sosial atau kecakapan antar personal (interpersonal skills) mencakup antara lain: kecakapan komunikasi dengan empati, dan kecakapan bekerja sama. Empati, sikap penuh pengertian dan seni komunikasi dua arah perlu ditekankan karena yang dimaksud berkomunikasi bukan sekedar menyampaikan pesan tetapi isi dan sampainya pesan disertai dengan kesan baik yang akan menumbuhkan hubungan harmonis. Keterampilan Sosial dapat berupa keterampilan komunikasi, manajemen marah, dan solusi konflik, situasi berteman dan menjadi bersama dengan teman kerja

${ }^{12}$ Nyimas Lisa Agustrian, et. al., "Manajemen Program Life Skill di Rumah Singgah Al-Hafidz Kota Bengkulu, ' Jurnal Pengembangan Masyarakat, I, 1, 2017, hal. 8

Anwar, Pendidikan Kecakapan Hidup (Life Skill Education) Konsep \& Aplikasi, Bandung: CV. Alfabeta, 2015, Cet. IV, hal. 20

${ }^{14}$ Ibid., hal. 29 
(co-workers) dan kawan sekamar. Sebagian besar bersandar pada praktek keterampilan untuk membantu seseorang lebih berkompeten secara sosial. ${ }^{15}$

c. Kecakapan Akademik (Academic Skill).

Kecakapan akademik merupakan kecakapan yang dimiliki seseorang di bidang akademik. Kecakapan akademik atau kemampuan intelektual atau kemampuan berpikir ilmiah merupakan sebuah pengembangan dari kecakapan berpikir secara umum tapi mengarah pada kegiatan yang bersifat keilmuan. Kecakapan akademik ini meliputi kecakapan mengidentifikasi variabel, menjelaskan hubungan suatu fenomena tertentu, merumuskan hipotesis, merancang dan melaksanakan penelitian. Diperlukan sikap ilmiah, kritis, obyektif da transparan untuk membangun kecakapan-kecakapan tersebut.

d. Kecakapan Vokasional (Vocational Skill).

Kecakapan vokasional ialah salah satu jenis kecakapan yang dikaitkan dengan berbagai bidang pekerjaan tertentu dalam masyarakat. Kecakapan vokasional meliputi: Kecakapan vokasional dasar berkaitan dengan bagaimana seseorang menggunakan alat sederhana, seperti obeng, palu dan lain sebagainya. Kecakapan vokasional khusus hanya diperlukan bagi mereka yang akan menekuni pekerjaan yang sesuai dengan bidangnya, seperti pekerja montir, apoteker, tukang, dan sebagainya. ${ }^{16}$

Jadi singkatnya pengembangan kecakapan hidup itu mencakup pengembangan kecakapan personal yaitu mengenali diri sendiri, kecakapan sosial yaitu kecakapan berkomunikasi baik melalui lisan ataupun tulisan, kecakapan akademik yaitu kecakapan intelektual, dan kecakapan vakasional yaitu kecakapan dalam bidang pekerjaan tertentu (kejuruan).

\section{Kemandirian}

Kemandirian berasal dari kata mandiri, dalam bahasa Jawa berarti berdiri sendiri. Kemandirian dalam arti psikologis adalah keadaan seseorang dalam kehidupannya yang mampu memutuskan atau mengerjakan sesuatu tanpa bantuan orang lain. ${ }^{17}$

\footnotetext{
${ }^{15}$ Ibid., hal. 30

${ }^{16}$ Ibid., hal. 31

${ }^{17}$ Rika Sa'diyah "Pentingnya Melatih Kemandirian Anak”, hal. 32.
} 
Menurut Havinghurst unsur kemandirian terdiri dari beberapa aspek, yaitu:

a. Aspek Emosi

aspek ini menekankan pada kemampuan seseorang dalam mengontrol emosi dan secara emosi tidak bergantung kepada orang lain. Hal ini berkaitan dengan bagaimana seseorang dapat mengambil keputusan sendiri, mampu mengontrol emosi dan menyelesaikan masalah sendiri.

b. Aspek Ekonomi

Aspek ini menunjukkan kemampuan seseorang dalam mengatur ekonomi dan tidak bergantungnya kebutuhan ekonomi pada orang lain. Hal ini berkaitan dengan bagaimana seseorang dapat menggunakan, mengatur keuangannya dengan baik, tidak bergantung kepada orang tua dan memiliki penghasilan sendiri. ${ }^{18}$

c. Aspek intelektual

Aspek ini menunjukkan kemampuan seseorang dalam mengatasi berbagai hambatan atau masalah yang dihadapi. Hal ini berkaitan dengan bagaimana seseorang dapat mengatasi masalah dari yang paling sederhana seperti mampu mengurus diri sendiri dalam kehidupan sehari-hari.

d. Aspek Sosial

Aspek ini menunjukkan kemampuan seseorang untuk mengadakan interaksi dengan orang lain dan tidak bergantung atau menunggu aksi dari orang lain. Hal ini berkaitan dengan bagaimana seseorang dapat bersosialisasi dengan orang lain, berteman, membantu orang lain atau teman yang kesulitan atas kemauannya sendiri tanpa menunggu perintah dari orang lain. ${ }^{19}$

\section{Anak}

J. Looke berpandangan bahwa jiwa anak bagaikan tabula rasa, sebuah meja lilin yang dapat ditulis dengan apa saja sebagaimana keinginan si pengajar. Tidak ada bedanya dengan sehelai kertas putih yang dapat

\footnotetext{
${ }^{18}$ Ibid., hal. 38

${ }^{19}$ Ibid.,
} 
ditulis dengan tinta berwarna apa saja, merah atau hitam, dan sebagainya.

Di Indonesia sendiri, juga terdapat beberapa pengertian tentang anak menurut peraturan perundang- undangan, begitu juga menurut para pakar ahli. Namun di antara beberapa pengertian tidak ada kesamaan mengenai pengertian anak tersebut, karena di latar belakangi dari maksud dan tujuan masing-masing undang-undang maupun para ahli.

Pengertian anak menurut peraturan perundang-undangan dapat dilihat sebagai berikut : "Anak Menurut UU No. 23 Tahun 2002 Tentang Perlindungan Anak. Pengertian anak berdasarkan Pasal 1 ayat (1) UU No 23 Tahun 2002 tentang Perlindungan Anak adalah seseorang yang belum berusia 18 (delapan belas) tahun, termasuk anak yang masih dalam kandungan". ${ }^{21}$

Menurut Pasal 1 butir 5 Undang-Undang Nomor 39 Tahun 1999 tentang Hak Asasi Manusia adalah sebagai berikut: "Anak adalah setiap manusia yang berusia di bawah 18 (delapan belas) tahun dan belum menikah, termasuk anak yang masih dalam kandungan apabila hal tersebut demi kepentingannya". Anak asuh adalah anak yang diasuh oleh seorang atau lembaga, untuk diberikan bimbingan, pemeliharaan, perawatan, pendidikan dan kesehatan, karena orang tuanya atau salah satu orang tuanya tidak mampu menjamin tumbuh kembang anak secara wajar. $^{22}$ Sementara Pasal 1 Angka 1 Undang-undang Republik Indonesia Nomor 35 Tahun 2014 tentang perubahan atas Undang-undang Republik Indonesia Nomor 23 Tahun 2002 tentang Perlindungan Anak, "anak adalah seseorang yang belum berusia 18 (delapan belas) tahun termasuk anak yang masih dalam kandungan. ${ }^{23}$

\section{METODE PENELITIAN}

\section{Pendekatan Penelitian}

Adapun pendekatan penelitian yang penulis lakukan adalah pendekatan penelitian deskriptif kualitatif. Peneliti melakukan penelitian

${ }^{20}$ Oemar Hamalik, Proses Belajar Mengajar, Jakarta: Bumi Aksara, Cet. III, 2004, hal. 101.

${ }^{21}$ Redaksi New Merah Putih, Undang-undang Perlindungan Anak, Yogyakarta: New Merah Putih 2009, hal. 12

${ }^{22}$ Ibid, hal. 13

${ }^{23}$ Ibid., hal. 12 
tentang "Model Program Pengembangan Life Skill untuk Kemandirian Anak di Panti Asuhan Budi Utomo Muhammadiyah Metro".

\section{Metode Pengumpulan Data}

Adapun langkah-langkah pengumpulan data dalam penelitian ini adalah sebagai berikut:

1. Observasi

Observasi merupakan proses pengamatan dan pencatatan dengan sistematis fenomena-fenomena yang diselidiki. Dalam penelitian ini peneliti menggunakan observasi partisipasi pasif. Yaitu dalam observasi peneliti datang di tempat kegiatan yang akan diamati, tetapi tidak ikut berpartisipasi dalam aktivitas kegiatan tersebut. ${ }^{24}$ Observasi ini peneliti lakukan di pada kegiatan-kegiatan yang dilaksanakan oleh Panti Asuhan Budi Utomo Muhammadiyah Metro.

2. Wawancara

Wawancara adalah bentuk komunikasi yang dilakukan antara dua orang, seorang yang ingin mendapatkan informasi dengan cara mengajukan pertanyaan-pertanyaan yang ingin diketahui atau berdasarkan tujuan. ${ }^{25}$

Dalam penelitian ini, peneliti menggunkan metode wawancara secara langsung dengan narasumber. Menggunakan metode wawancara tak terstruktur atau sering disebut wawancara secara mendalam. Karena wawancara tak terstruktur ini bersifat luwes susunan kata-katanya dalam setiap pertanyaan dapat diubah saat proses wawancara. Menyesuaikan kondisi saat wawancara. ${ }^{26}$ Wawancara ini peneliti lakukan kepada pengurus dan anak Panti Asuhan Budi Utomo Muhammadiyah Metro.

3. Dokumentasi

Teknik pengumpulan data selanjutnya yang digunakan dalam penelitian ini adalah dokumentasi. Dengan menganalisis dokumen yang ada seperti surat-surat, foto-foto dan lain-lain yang ada di Panti Asuhan Budi Utomo Muhammadiyah Metro.

${ }^{24}$ Sugiono, Metode Penelitian Menejemen, Bandung Bandung: Alfabeta, 2015, hal 378

${ }^{25}$ Deddy Mulyana, Metodologi Penelitian Kualitatif, Bandung: PT Remaja Rosdakarya, 2006, Cet. V, hal. 180

${ }^{26}$ Ibid., 181 


\section{Teknik Analisis Data}

Setelah data terkumpul, maka data akan dianalisis dengan menggunakan teknik analisis data kualitatif. Menurut Miles dan Huberman Analisis data kualitatif adalah mereduksi data, menyajikan data dan menarik kesimpulan. Reduksi data dapat diartikan sebagai kegiatan pemilihan data penting dan tidak penting dari data yang telah terkumpul. Penyajian data mereka artikan sebagai penyajian informasi yang tersusun. $^{27}$

Kesimpulan data mereka artikan sebagai tafsiran atau interpretasi terhadap data yang telah disajikan. Hal penting dari definisi Miles dan Huberman adalah analisis data dalam penelitian kualitatif bukan kegiatan menghitung (kuantitatif). Adapun model analisis data menurut Miles dan Huberman adalah sebagai berikut:

1. Penyajian Data (Data Display)

Setelah data direduksi, maka langkah selanjutnya adalah data display. Display dalam konteks ini adalah kumpulan informasi yang telah tersusun yang membolehkan penarikan kesimpulan dan pengambilan tindakan. Bentuk display data dalam penelitian kualitatif yang paling sering yaitu teks naratif dan kejadian atau peristiwa itu terjadi di masa lampau. ${ }^{28}$ Akan tetapi sebelum data disajikan, data harus diklasifikasikan terlebih dahulu. Dan yang paling sering digunakan untuk menyajikan data dalam penelitian kualitatif adalah dalam bentuk uraian singkat dan teks yang bersifat naratif. Dengan menyajikan data maka akan memudahkan untuk memahami apa yang terjadi, merencanakan kerja selanjutnya berdasarkan apa yang telah dipahami.

2. Reduksi Data (Data Reduction)

Reduksi data menunjuk kepada proses pemilihan, pemfokusan, penyederhanaan, pemisahan, dan pentransformasian data "mentah" yang terlihat dalam catatan tertulis lapangan. ${ }^{29}$ Reduksi data adalah kegiatan yang tidak terpisahkan dari analisis data. Reduksi data adalah suatu bentuk analisis yang mempertajam, memilih, memfokuskan,

27 Sugiono, Metode Penelitian Kualitatif untuk Penelitian yang Bersifat Eksploratif Enterpretif, Interaktif dan Konstruktif, hal. 133

${ }^{28}$ Imam Gunawan, Metode Penelitian Kualitatif Teori \& Praktek, hal. 409

29 Muri Yusuf, Metode Penelitian Kuantitatif Kualitatif dan Penelitian Gabungan, hal. 407-408 
membuang, dan mengorganisasikan data dalam satu cara, dimana kesimpulan akhir dapat digambarkan dan diverifikasikan. Mereduksi data berarti merangkum, memilih hal-hal yang pokok, memfokuskan pada hal-hal yang penting, dicari tema dan polanya dan membuang data yang tidak perlu.

Dengan demikian data yang direduksi akan memberikan gambaran yang lebih jelas tentang hasil pengamatan dan mempermudah peneliti untuk melakukan pengumpulan data selanjutnya, dan mencarinya jika diperlukan. Dalam mereduksi data, setiap peneliti akan dipandu oleh tujuan yang akan dicapai. Tujuan utama daru penelitian kualitatif adalah pada temuan. Oleh karena itu, jika peneliti dalam melakukan penelitian menemukan segala sesuatu yang dipandang asing, tidak dikenal, belum memiliki pola, justru itulah yang harus dijadikan perhatian peneliti dalam melakukan reduksi data.

3. Penarikan Kesimpulan (Conclution Drawing)

Langkah ke tiga dalam analisis data kualitatif menurut Miles and Huberman adalah penarikan kesimpulan dan verifikasi. Kesimpulan awal yang dikemukakan masih bersifat sementara, dan akan berubah bila tidak ditemukan bukti-bukti yang kuat yang mendukung pada tahap pengumpulan data berikutnya. Tetapi apabila kesimpulan yang dikemukakan pada tahap awal, didukung oleh bukti-bukti yang valid dan konsisten saat peneliti kembali ke lapangan mengumpulkan data, maka kesimpulan yang dikemukakan merupakan kesimpulan yang kredibel. $^{30}$

\section{HASIL DAN PEMBAHASAN}

\section{Letak Geografis Panti Asuhan Budi Utomo Muhammadiyah Metro}

Pada awalnya Panti Asuhan Budi Utomo Muhammadiyah Metro menempati sebuah bangunan gribik di dekat lokasi pasar Metro (sekarang adalah gedung Wali Kota Metro). Karena pengembangan tata kota, bangunan tersebut oleh Pemerintah Daerah Kota Metro di pindahkan ke lokasi komplek Muhammadiyah yaitu Jl. K.H. Ahmad Dahlan depan Mapolres Metro, dengan areal mulai depan Mapolres Metro hingga

\footnotetext{
${ }^{30}$ Sugiono, Metode Penelitian Kuantitatif Kualitatif dan $R \& D$, hal. 252
} 
terminal Kota Metro (sekarang menjadi Pondok Pesantren Darul Arqom Putri Muhammadiyah Metro).

Karena pesatnya pengembangan kota dan pendidikan mengakibatkan pengaruh negatif terhadap anak asuh panti (terlalu dekat dengan pasar dan terminal) maka pada tahun 1981 diupayakan pemindahan lokasi ke komplek sekarang yaitu di (Jl. Khairbras No. 69 Ganjarasri 14/IV Metro Barat Kota Metro). ${ }^{31}$ Tempat di atas areal yang luasnya kurang lebih 1,5 $\mathrm{Ha}$ ini dibangun: 2 (dua) buah Cottage (Asrama keluarga), 1 (satu) kantor, 1 (satu) buah dapur umum, 1 (satu) buah Aula dan 1 (satu) buah masjid. ${ }^{32}$

\section{Profil Panti Asuhan Budi Utomo Muhammadiyah Metro}

Panti Asuhan Budi Utomo Muhammadiyah Metro adalah panti asuhan tertua di Propinsi Lampung. sejarah berdirinya panti tersebut dirintis pendiriannya sejak 20 Mei tahun 1946 oleh beberapa umat Islam yang peduli pada masalah sosial keagamaan. ${ }^{33}$ Beberapa orang tersebut adalah mereka yang aktif di MASYUMI, diantaranya K.H. Muhammad Khajat (Alm. penghulu pertama Kota Metro), K.H. Muhammad Yasin (Alm), K.H. Muhammad Asyrof (Alm), H. Abdul Muntholib (Alm), K.H. Arsyad (Alm), K.H. Sosro Sudarmo (Alm) ${ }^{34}$

- Karena terlalu padatnya kegiatan partai pada waktu itu, maka mereka menjalin kerja sama dengan Muhammadiyah yang secara resmi pengelolaanya diserahkan kepada Muhammadiyah pada tahun 1952.

Latar Belakang Didirikannya Panti Asuhan ini adalah di dorong oleh beberapa situasi pada saat itu, antara lain:

a. Banyaknya janda dan wanita jompo yang ditinggal mati/hilang oleh suami mereka ketika menjalani ROMUSHA (pada masa penjajahan Jepang maupun ketika memperjuangkan dan mempertahankan kemerdekaan Republik Indonesia

\footnotetext{
${ }^{31}$ Muzakir, Ketua Panti Asuhan Budi utomo, Wawancara, Metro, 17 Desember 2019

${ }^{32}$ Ismail, Panti Asuhan Budi utomo Muhammadiyah Metro, Catatan Lapangan, Metro, 19 Desember 2019

${ }^{33}$ Ari Febrian, Panti Asuhan Budi Utomo Muhammadiyah Metro, Wawancara, Metro, 17 Desember 2019

${ }^{34}$ Sumber: Dokumentasi Panti Asuhan Budi utomo Muhammadiyah Metro, 20 Desember 2019
} 
b. Banyaknya anak-anak penyandang status sosial seperti; yatim, piatu, yatim piatu, maupun terlantar karena situasi di atas

c. Memenuhi panggilan Allâh SWT sebagaimana tercantum di dalam QS Al-Ma un ayat 1-3

d. Menjalankan amanat UUD 45 pasal $34 .^{35}$

\section{Visi dan Misi Panti Asuhan Budi Utomo Muhammadiyah Metro}

Visi Panti Asuhan Budi Utomo Muhammadiyah Metro adalah Tersantuni, takwa, cerdas, trampil dan mandiri.

Sedangkan untuk misi panti asuhan Budi Utomo Muhammadiyah Metro yaitu:

a. Meningkatkan kwalitas iman dan taqwa.

b. Menyiapkan ketrampilan hidup (Life Skill).

c. Meningkatkan mutu pelayanan terhadap klien dan masyarakat.

d. Membangun kecerdasan majemuk (Multiple Intelligence).

e. Meningkatkan partisipasi masyarakat dalam usaha kesejahteraan

f. Melatih berserikat dan bermasyarakat.

g. Mewujudkan panti yang ideal.

Secara umum tujuan Panti Asuhan Budi Utomo Muhammdiyah Metro adalah terwujudnya manusia muslim yang cerdas, berakhlak mulia, terampil dan percaya pada diri sendiri, mandiri serta berguna bagi agama, persyarikatan, masyarakat, bangsa dan negara. ${ }^{36}$

\section{Pengembangan Life Skill Panti Asuhan Budi Utomo}

Berdasarkan hasil penelitain yang peneliti lakukan pengembangan Life Skill untuk kemandirian anak di Panti Asuhan Budi Utomo Muhammadiyah Metro adalah sebagai berikut:

\section{Mengembangkan Kecakapan Personal (Personal Skill)}

Kecakapan personal merupakan kecakapan yang diperlukan bagi seseorang untuk mengenal dirinya secara utuh, yang termasuk di dalamnya yaitu penghayatan sebagai makhluk Allâh, menyadari dan mensyukuri kelebihan dan kekurangan yang dimilikinya dan dapat ditingkatkan dengan potensi berpikir. Kecakapan personal sangat

${ }^{35}$ Sumber: Dokumentasi Panti Asuhan Budi utomo Muhammadiyah Metro, 20 Desember 2019

${ }^{36}$ Muzakir, Ketua Panti Asuhan Budi utomo, Wawancara, Metro, 17 Desember 2019 
membantu anak untuk mengenal jati dirinya, mengetahui tugasnya terhadap Allâh dan kepada sesama manusia.

Dengan adanya pengembangan kecakapan personal, dengan sendirinya anak akan menyadari kelebihan dan kekurangan dirinya, dan menimbulkan motivasi untuk meningkatkan potensi diri untuk menjadi yang lebih baik. Selain itu, anak akan bertindak atas kemauannya sendiri dan bukan karena bergantung dengan orang lain.

Pengembangan Life Skill dalam hal Kecakapan Personal (Personal Skill) untuk Kemandirian Anak dilakukan oleh Panti Asuhan Budi Utomo Muhammadiyah Metro Melalui Pendidikan keagamaan. Pengembangan life skill (kecakapan hidup) melalui Pendidikan Keagamaan diwujudkan dengan pembelajaran pendidikan keagamaan semi pondok pesantren di panti asuhan Budi Utomo Muhammadiyah Metro. Pendidikan keagamaan ini dibagi menjadi tiga kelas, yaitu: kelas wusthâ putra (SD/SMP sederajat), kelas wusthâ putri (SD/SMP sederajat), dan kelas ulyâ (SMA/SMK sederajat). ${ }^{37}$

Adapun kegiatan pengembangan life skill melalui pendidikan keagamaan untuk kelas wusthâ putra adalah aqidah akhlak, Târikh Islâm, fiqih ibadah, Tahsin/ilmu Tajwid al-Qur`an, hafalan Qur`an, terjemah dan tafsir Qur an, dan Kemuhammadiyahan.

Dan untuk kelas wusthâ putri adalah aqidah akhlak, Târikh Islâm, fiqih ibadah, fiqih wanita, Tahsin/ilmu Tajwid al-Qur`an, hafalan Qur`an, terjemah dan tafsir Quran, serta Kemuhammadiyahan. Sedangkan kegiatan pembelajaran pendidikan keagamaan untuk kelas ulyâ yaitu ilmu tauhid atau aqidah, ilmu akhlak, konsepsi ibadah, Târikh Islâm, hadits dan ilmu hadits, hafalan Qur`an, termejah al-Qur`an/tafsir, ilmu al-Qur`an dan tafsir, Kemuhammadiyahan. Untuk kegiatan Pengajian PCM Metro Barat diikuti oleh seluruh anak panti asuhan, pengurus dan jamaah sekitar. $^{38}$

Pelaksanaan kegiatan pengembangan life skill melalui pendidikan dan keagamaan sesuai dengan jadwal yang ada di panti asuhan. Pada aqidah akhlak kelas wusthâ putra dilaksanakan pada hari Senin, setelah shalat maghrib dan sebagai pemateri adalah Ustadz Sangidun Hamid, M.Kom.I., dengan menggunakan kitab tauhid. Adapun pelajaran Târikh Islâm,

\footnotetext{
${ }^{37}$ Muzakir, Ketua Panti Asuhan Budi Utomo Muhammadiyah Metro, Wawancara, Metro, 15 Agustus 2020

${ }^{38}$ Sumber: Dokumentasi Panti Asuhan Budi Utomo Muhammadiyah Metro, 23 Desember 2019
} 
dilaksanakan pada hari Sabtu, setelah shalat shubuh yang menjadi pemateri adalah Ustadz Eko Nugroho, S.Pd., dengan menggunakan kitab Târikh. Selanjutnya untuk fiqih ibadah dilaksanakan pada hari Kamis, setelah shalat shubuh dan sebagai pemateri adalah Ustadz Ismail, S. Ag, menggunakan kitab Himpunan Putusan Tarjih. Untuk Kemuhammadiyahan dilaksanakan setiap hari Jum'at setelah shalat maghrib oleh Ustadz Samsul Hadi, S.Pd., menggunakan kitab PHIM (Pedoman Hidup Islami Warga Muhammadiyah)..$^{39}$

Kemudian tahsin/ilmu tajwid al-Qur'an dilaksanakan setiap hari Selasa, setelah shalat maghrib sebagai pemateri adalah Ustadz Nur Hanifurrahman, S. Kom.I., menggunakan kitab al-Qur'an. Selanjutnya hafalan Qur'an dilaksanakan pada hari Senin sampai Jum'at, sebagai pemateri adalah Ustadz Rudi Setiawan, S. Pd., menggunakan kitab alQur`an. Terakhir adalah terjemah dan tafsir Qur`an dilaksanakan pada hari Rabu, setelah selesai shalat shubuh sebagai pemateri yaitu Ustadz Deaqurrahman, S.Pd., menggunakan kitab al-Qur`an. ${ }^{40}$

Sedangkan untuk kelas wusthâ putri pada aqidah akhlak dilaksanakan pada hari Senin setelah shalat maghrib, sebagai pemateri yaitu Ustadz Ahmad Rifa 'i, S. Kom.I., menggunakan kitab tauhid. Kemudian untuk Târikh Islâm dilaksanakan setiap hari Selasa setelah shalat shubuh, sebagai pemateri adalah Ustadz Eko Nugroho, S. Pd., dengan menggunakan kitab Târikh. Setelah itu untuk fiqih ibadah yang dilaksanakan setiap hari Jum'at setelah shalat shubuh, sebagai pemateri adalah Ustadz Ismail, S.Ag., menggunakan kitab fiqih dan al-Qur`an.

Selanjutnya untuk fiqih wanita dilaksanakan setiap hari Sabtu setelah shalat shubuh, sebagai pemateri yaitu Ustadzah Yeti Aulia Sari, S. Pd.I., dengan menggunakan kitab fiqih. Tahsin/ilmu Tajwid al-Qur'an dilaksanakan hari Jum'at setelah shalat maghrib, pemateri adalah Ustadz Nur Hanifurrahman, S. Kom.I dengan kitab al-Qur`an.

Dan untuk hafalan Qur`an dilaksanakan setiap hari Senin sampai dengan Jum'at, sebagai pemateri adalah Ustadz Ismail, S.Ag., Kemudian terjemah dan tafsir Qur`an dilaksanakan setiap hari Kamis setelah shalat shubuh, sebagai pemateri adalah Ustadz Daequrrahman, S.Pd., Untuk

\footnotetext{
${ }^{39}$ Sumber: Dokumentasi Panti Asuhan Budi Utomo Muhammadiyah Metro, 23 Desember 2019

${ }^{40}$ Sumber: Dokumentasi Panti Asuhan Budi Utomo Muhammadiyah Metro, 23 Desember 2019
} 
Kemuhammadiyahan dilaksanakan setiap hari Ahad setelah selesai shalat maghrib oleh Ustadz Samsul Hadi, S.Pd., menggunakan buku KMD/ PHIM (Pedoman Hidup Islami Warga Muhammadiyah).

Sedangkan pelaksanaan kegiatan model pengembangan life skill melalui pendidikan dan keagamaan kelas 'ulyâ sesuai dengan jadwal yang ada di panti asuhan. ilmu tauhid/aqidah dilaksanakan pada hari Selasa setelah shalat maghrib, pemateri oleh Ustadz Sangidun Hamid, M. Kom.I., menggunakan kitab Mizânul Muslim. Ilmu akhlak dilaksanakan hari Selasa setelah shalat shubuh, pemateri adalah Ustadz Ismail, S.Ag. ${ }^{41}$

Konsepsi ibadah dilaksanakan setiap hari Kamis setelah shalat maghrib sebagai pemateri adalah Ustadz Ismail, S. Ag., menggunakan kitab Himpunan Putusan Tarjih/ kitab ibadah. Târikh Islâm dilaksanakan setiap hari Jum'at setelah shalat shubuh, pemateri Ustadz Eko Nugroho S. Pd., dengan kitab Sirah Nabawiyyah. Hadits dan ilmu hadits dilaksanakan setiap hari Kamis setelah shalat shubuh, sebagai pemateri yaitu Ustadz Sangidun Hamid, M.Kom.I., menggunakan kitab Ilmu Hadits.

Hafalan Qur`an dilaksanakan setiap hari Senin sampai Sabtu, sebagai pemateri adalah Ustadz Eko Nugroho, S. Pd., Termejah al-Qur`an/tafsir dilaksanakan pada hari Ahad setelah shalat maghrib, pemateri Ustadz Ismail, S.Ag., Ilmu al-Qur an dan tafsir dilaksanakan setiap hari Sabtu setelah shalat shubuh, pemateri adalah Ustadz Nur Hanifurrahman, S. Kom.I., dan untuk Kemuhammadiyahan dilaksanakan setiap hari Ahad setelah selesai shalat maghrib oleh Ustadz Samsul Hadi, S. Pd., menggunakan buku KMD/ PHIM (Pedoman Hidup Islami Warga Muhammadiyah). ${ }^{42}$

Dengan berjalannya personal skill (kecakapan personal) membuahkan hasil bagi anak-anak panti asuhan. Dari anak panti yang tadinya tidak cakap dalam baca tulis abjad dan al-Qur an, kini dapat melakukannya bahkan sudah bisa menghafal ayat dari al-Qur an. Adanya pengembangan kecakapan personal di panti asuhan Budi Utomo Muhammadiyah Metro menjadikan bertambahnya ilmu pengetahuan dan keagamaan yang dirasakan oleh anak panti asuhan.

\footnotetext{
${ }^{41}$ Sumber: Dokumentasi Panti Asuhan Budi Utomo Muhammadiyah Metro, 23 Desember 2019

42 Muzakir, Ketua Panti Asuhan Budi Utomo Muhammadiyah Metro, Wawancara, Metro, 15 Agustus 2020
} 
Dari anak panti yang tidak memiliki kepercayaan diri, tidak mengetahui siapa dirinya dan tidak tahu ingin kemana nanti, akhirnya perlahan dapat mengetahui perannya dengan bekal yang telah mereka miliki. Anak panti asuhan Budi Utomo Muhammadiyah Metro dapat mengerjakan tutgas-tugas di panti dengan mandiri, melakukan ibadah dengan tertib dan juga dapat menjaga diri mereka sendiri dengan bela diri yang mereka miliki. Dengan hal tersebut, akan terbangun kedisiplinan pada anak dan menjadi pribadi yang bertanggung jawab.

Dengan mengenal hakikat dirinya, mengetahui apa tugas anak di dunia, untuk apa ia diciptakan dan tujuannya kemana, anak dapat menjawab dan mengatasi suatu permasalahan.

\section{Mengembangkan Kecakapan Sosial (Social Skill)}

Kecakapan sosial merupakan kecakapan berkomunikasi yaitu kemampuan mendengarkan dan menyampaikan gagasan yang dilakukan dengan lisan maupun tulisan. Kesulitan anak untuk berkomunikasi, bersosialisasi dan berani tampil di muka umum menjadi sebuah permasalahan. Hal itu disebabkan karena berbagai hal dari kurangnya mental, perasaan takut ataupun malu dan juga tidak memiliki kecakapan atas apa yang akan disampaikan.

Kecakapan berkomunikasi merupakan bagian penting dari kemampuan anak. Tanpa memiliki kecakapan sosial, anak akan sulit untuk berinteraksi dengan orang lain. Bagi anak yang memiliki rasa takut untuk berbicara di depan, akan muncul rasa panik yang mengganggu. Saat belum mulai berbicara di depan umum, tubuh yang belum siap akan menunjukkan tanda-tanda awal reaksi panik akibat tekanan harus maju di depan. Detak jantung menjadi semakin cepat, telapak tangan berkeringat dan kedua kaki menjadi gemetar. Hal ini terjadi karena kurangnya peningkatan kecakapan sosial dalam berbicara di depan umum.

Bagitu pula sebaliknya anak yang mempunyai kecakapan sosial akan mudah berinteraksi dengan orang lain, mampu melakukan kegiatankegiatan sebagai makhluk sosial dan bisa menempatkan posisinya di masyarakat.

Pengembangan Life Skill untuk Kemandirian Anak Melalui melalui model ini dilakukan dengan cara meningkatkan Keterampilan Interpersonal (Komunikasi Sosial).

Kegiatan yang dilakukan di Panti Asuhan Budi Utomo Muhammadiyah Metro untuk pengembangan kecakapan sosial pada anak 
panti asuhan adalah mubâdharah yaitu latihan khutbah, pidato, ceramah dan bahasa Arab. ${ }^{43}$

Kegiatan Mubâdharab dilaksanakan setiap hari Sabtu malam Ahad yang dibina oleh ketua Asrama atau Bidang Pendidikan/terjadwal. Sedangkan untuk bahasa Arab pada kelas wusthâ putra dilaksanakan pada hari Ahad setelah shalat maghrib, pemateri yaitu Ustadz Endra S.Kom.I dengan kitab Durûsul-lughah. Untuk kelas wusthâ putri dilaksanakan pada hari Kamis setelah shalat maghrib, oleh Ustadz Ahmad Rifa'i, S.Kom.I dengan menggunakan kitab bahasa Arab. ${ }^{44}$

Anak panti asuhan dituntut untuk berpidato ataupun berceramah dengan menggunakan materi, gaya bahasa yang sebaik-baiknya.. Semua ini bertujuan untuk menjadikan juru da'wah yang baik, dan sebagai penerus yang akan meneruskan estafet calon muballigh yang akan melaksanakan tugas da'wah di masyarakat pada masa yang akan datang

Selain muahadharah, pengembangan kecakapan sosial yang dilakukan di Panti Asuhan Budi Utomo Muhammadiyah Metro kepada para anak asuhnya juga memberikan materi bahasa Arab. Materi yang diberikan tidak hanya dari segi pelafalan saja, tetapi juga dari segi mengartikan makna setiap kalimat. Dengan memiliki kecakapan dalam bahasa Arab, anak mempunyai hafalan kosakata bahasa arab, dapat menulis menggunakan bahasa arab serta dapat menggunakannya dalam percakapan sehari-hari. Dengan hal tersebut, akan mempercepat untuk memperdalam pemahaman tentang agama Islam yang nantinya akan disampaiakan kepada masyarakat.

\section{Mengembangkan Kecakapan Vakasional}

Kecakapan vokasional ialah salah satu jenis kecakapan yang dikaitkan dengan berbagai bidang pekerjaan tertentu. Kecakapan vakasional merupakan kemampuan individu mewujudkan suatu karya atau menghasilkan suatu barang atau jasa. Keadaan anak seperti kertas putih yang dapat ditulis dengan tinta berwarna apa saja. Pada pengembangan kecakapan vakasional ini anak dibekali beberapa keterampilan.

Permasalahan anak tidak memiliki keterampilan, belum mengetahui

${ }^{43}$ Sumber: Dokumentasi Panti Asuhan Budi Utomo Muhammadiyah Metro, 24 Desember 2019

${ }^{44}$ Ari Febrian, Ketua Tata Usaha Panti Asuhan Budi Utomo Muhammadiyah Metro, Wawancara, Metro, 13 September 2020 
siapa dirinya, serta akan menjadi apa nanti, dengan adanya pengembangan life skill vakasional, anak-anak panti asuhan dapat berperan dan mengembangkan kecakapannya menjadi terarah kepada kegiatan-kegiatan yang positif, kreatif dan produktif, yang nantinya dapat menggali bakatbakat pada anak.

Pengembangan Life Skill untuk Kemandirian Anak melalui model ini dilakukan dengan cara melatih anak-anak dalam hal pertanian, tataboga, peternakan, dan kerajinan tangan.

Dalam hal pertanian, mereka dilatih untuk bercocok tanam, seperti menanam cabai, jambu, pepaya, singkong, bunga-bunga. Ada juga tanaman singkong yang bisa dikonsumsi atau menghasilkan. ${ }^{45}$ Adapun dalam hal peretrnakan mereka dilatih untuk beternak ayam dan lele. dan hasil penjualannya untuk akan dimanpaatkan oleh anak-anak asuh panti asuhan Budi Utomo. ${ }^{46}$

Dalam hal tata boga merupakan pengetahuan di bidang pengolahan makanan yang mencakup ruang lingkup makanan, mulai dari persiapan pengolahan sampai dengan menghidangkan makanan itu sendiri. Aplikasi kegiatan ini diantaranya memasak nasi, membuat gulai dari daging baik daging sapi atau daging kambing, memanggang atau membakar baik daging ayam, kambing atau ikan, menggoreng tempe, menumis atau memasak sayuran, membuat bakso dan juga membuat roti. ${ }^{\text {,47 }}$

Adapun tujuannya dari semua kegiatan di atas adalah mengembangkan keterampilan yang perlu dimiliki untuk dapat menunjang profesi yang diinginkan untuk meraih cita-cita.

Manfaat dari kegiatan menanam selain menciptakan rasa peduli tarhadap lingkungan, kebersihan, dan keindahan, hasil dari yang di tanam tersebut dapat di konsumsi dan menjadi sumber penghasilan. Selain itu, hasil dari kegiatan memasak yaitu, anak dapat mengetahui ilmu dan keterampilan dalam memasak, sehingga sudah bisa mandiri jika setelah dari panti atau berada di masyarakat.

Kemudian hasil yang didapatkan oleh anak dari beternak lele/ayam adalah mempunyai pengetahuan bagaimana beternak lele atau ayam.

45 Muzakir, Ketua Panti Asuhan Budi Utomo Muhammadiyah Metro, Wawancara, Metro, 20 September 2020

${ }^{46}$ Sumber: Dokumentasi Panti Asuhan Budi Utomo Muhammadiyah Metro, 25 Agustus 2020.

${ }^{47}$ Ari Febrian, Ketua Tata Usaha Panti Asuhan Budi Utomo Muhammadiyah Metro, Wawancara, Metro, 5 September 2020 
Adapun manfaat dari beternak lele/ayam hasilnya dapat di rasakan oleh anak dan kemaslahatan panti asuhan. Selain itu tujuan dari kegiatan tersebut sebagai bekal dasar dan menjadi kecakapan hidup untuk anak yang dapat digunakan dan dikembangkan di masa yang akan datang.

Selanjutnya hasil dari kerajinan tangan adalah anak mampu berkreasi dengan memanfaatkan barang-barang bekas, bahkan barang yang tadinya tidak digunakan menjadi barang yang berguna bahkan memiliki nilai, dengan hal tersebut maka anak akan memiliki kemandirian dalam diri.

\section{Mengembangkan Kecakapan Akademik}

Untuk meningkatkan kecakapan akademik Panti Asuhan Budi Utomo Muhammadiyah Metro membentuk model pendidikan semi pondok pesantren yang dilaksakan di panti asuhan Budi Utomo Muhammadiyah Metro. Pendidikan keagamaan ini dibagi menjadi tiga kelas, yaitu: kelas wusthâ putra (SD/SMP sederajat), kelas wusthâ putri (SD/SMP sederajat), dan kelas 'ulyâ (SMA/SMK sederajat). ${ }^{48}$

Melalui sekolah tersebut anak panti mengembangkan kecakapan akademiknya. Mereka diberikan pengetahuan baik pelajaran agama maupun pelajaran umum. Dengan pengembangan kecakapan akademik, anak mendapat ilmu pengetahuan, keterampilan berpikir ilmiah, berpikir kritis dan mandiri. Hasilnya anak dapat membuat keputusan dan mencari solusi, serta menyelesaikan masalahnya secara mandiri. Dan semua itu, akan menjadi bekal yang baik untuk anak saat ia tumbuh dewasa.

\section{PENUTUP}

Berdasarkan hasil penelitian, Panti Asuhan Budi Utomo Muhammadiyah Metro telah berusaha melakukan kegiatan-kegiatan yang dapat mengembangkan Life Skill untuk kemandirian Anak-anak asuhnya. Pengembangan life skill untuk kemandirian anak-anak asuh tersebut paling tidak dilakukan dengan cara pengembangan Life Skill untuk Kemandirian Anak Melalui pendidikan baik agama maupun umum, melalui keterampilan komunikasi, melalui tata boga, melaui pertanian, melalui Kesenian, dan melalui peternakan.

\footnotetext{
${ }^{48}$ Muzakir, Ketua Panti Asuhan Budi Utomo Muhammadiyah Metro, Wawancara, Metro, 15 Agustus 2020
} 


\section{DAFTAR PUSTAKA}

Agustrian, Nyimas Lisa, et. al., "Manajemen Program Life Skill di Rumah Singgah Al-Hafidz, Kota Bengkulu," Jurnal Pengembangan Masyarakat, I, 1, 2017.

Anwar, Pendidikan Kecakapan Hidup (Life Skill Education) Konsep \& Aplikasi, Bandung: CV. Alfabeta, 2015.

Arianty, Nel, Manajemen Sumber Daya Manusia, Medan: Perdana Publishing, 2016.

Gunarsa, Singgih D, "Dasar Dan Teori Perkembangan Anak", Jakarta: Libri, 2011.

Gunawan, Imam, Metode Penelitian Kualitatif Teori \& Praktek, Jakarta: Bumi Aksara, 2013.

Hamalik, Oemar, Proses Belajar Mengajar, Jakarta: Bumi Aksara, 2004.

Machendrawaty, Nanih, dan Agus Ahmad Safei, Pengembangan Masyarakat Islam dari Ideologi, Strategi sampai Tradisi, Bandung: PT. Remaja Rosdakarya, 2001.

Mulyana, Deddy, Metodologi Penelitian Kualitatif, Bandung: PT Remaja Rosdakarya, 2006

Pusat Pembinaan dan Pengembangan Bahasa, Kamus Besar Bahasa Indonesia Edisi Kedua, Jakarta: Balai Pustaka, 1999.

Redaksi New Merah Putih, Undang-undang Perlindungan Anak, Yogyakarta: New Merah Putih, 2009.

Sa'diyah, Rika, "Pentingnya Melatih Kemandirian Anak", Kordinat, XVI, 1, April, 2017.

Sarwono, Sarlito W, Psikologi Remaja Edisi Revisi, Jakarta: Raja Grafindo Persada, 2010.

Shaumi, Ayu Nur, "Pendidikan Kecakapan Hidup (Life Skill) dalam Pembelajaran SAINS di SD/MI", Jurnal Pendidikan dan Pembelajaran Dasar, II, 2, Desember, 2015.

Sugiono, Metode Penelitian Kualitatif untuk Penelitian yang Bersifat Eksploratif Enterpretif, Interaktif dan Konstruktif, Bandung: Alfabeta, 2017.

Sugiono, Metode Penelitian Menejemen, Bandung Bandung: Alfabeta, 2015

Eksis Sindonews, website: https://eksis.sindonews.com/ 29 Desember 2019.

Andi Prastino, Anak Panti Asuhan Budi Utomo Muhammadiyah Metro, Wawancara, Metro, 24 Oktober 2020.

Ari Febrian, Ketua Tata Usaha Panti Asuhan Budi Utomo Muhammadiyah Metro, Wawancara, Metro 20 September 2020. 
Dini Hana Listi, Anak Panti Asuhan Budi Utomo Muhammadiyah Metro, Wawancara, Metro, 24 Oktober 2020.

Dwi Amelia Putri, Anak Panti Asuhan Budi Utomo Muhammadiyah Metro, Wawancara, Metro, 24 Oktober 2020.

Faqih Bani Putra, Anak Panti Asuhan Budi Utomo Muhammadiyah Metro, Wawancara, Metro, 24 Oktober 2020.

Fatmawati Eliza Simanjuntak, Anak Panti Asuhan Budi Utomo Muhammadiyah Metro, Wawancara, Metro, 24 Oktober 2020.

Ismail, Ketua Bidang Pendidikan Panti Asuhan Budi Utomo Muhammadiyah Metro, Wawancara, Metro, 20 September 2020.

Muzakir, Ketua Panti Asuhan Budi Utomo Muhammadiyah Metro, Wawancara, Metro, 20 September 2020.

Nur Ana Fauziah, Anak Panti Asuhan Budi Utomo Muhammadiyah Metro, Wawancara, Metro, 24 Oktober 2020.

Qul Robbi Alfina Rahmah, Anak Panti Asuhan Budi Utomo Muhammadiyah Metro, Wawancara, Metro, 24 Oktober 2020.

Ropingi, Anak Panti Asuhan Budi Utomo Muhammadiyah Metro, Wawancara, Metro, 24 Oktober 2020.

Selly Susanti, Anak Panti Asuhan Budi Utomo Muhammadiyah Metro, Wawancara, Metro, 24 Oktober 2020.

Usamah Ihsan, Anak Panti Asuhan Budi Utomo Muhammadiyah Metro, Wawancara, Metro, 24 Oktober 2020.

Dokumentasi (Observasi)

Sumber: Dokumentasi Panti Asuhan Budi Utomo Muhammadiyah Metro, Desember 2019 